\title{
Energy and nutrient intake in preschool and school age Mexican children: National Nutrition Survey 1999
}

Simón Barquera, MD, MSc, ${ }^{(1)}$ Juan A Rivera, MS, PhD, (1) Margarita Safdie, MSC, ${ }^{(1)}$ Mario Flores, MD, MSc, ${ }^{(1)}$ Ismael Campos-N onato, MD, ${ }^{(1)}$ Fabricio Campirano, MSc, ${ }^{(1)}$

Barquera S, Rivera JA, Safdie, Flores M, Campos-Nonato I, Campirano F.

Energy and nutrient intake in preschool and school age Mexican children: National Nutrition Survey 1999.

Salud Publica Mex 2003;45 suppl 4:S540-S550.

The English version of this paper is available too at: http://www.insp.mx/salud/index.html

\begin{abstract}
A bstract
Objective.To estimate energy and nutrient intake and adequacy in preschool and school age Mexican children, using the N ational N utrition Survey 1999 (N N S-1999). Material and Methods. Twenty four-h dietary recalls from pre-school $(n=1309)$ and school ( $n=2611)$ children obtained from a representative sub-sample of the N N S-1999 were analyzed. Intakes and adequacies were estimated and compared across four regions, socio-economic strata, and between urban and rural areas, and indigenous vs. non-indigenous children. Results. Median energy intake in pre-school children was $949 \mathrm{kcal}$ and in school children $1377 \mathrm{kcal}$, with adequacies $<70 \%$ for both groups. Protein adequacy was $>150 \%$ in both age groups. The North and Mexico C ity regions had the highest fat intake and the lowest fiber intake. Children in the South region, indigenous children, and those in the lowest socio-economic stratum had higher fiber and carbo hydrate intakes and the lowest fat intake.These children also showed the highest risks of inadequacies for vitamin A, vitamin C, folate, iron, zinc and calcium. Conclusions Mexico is experiencing a nutrition transition with internal inequalities across regions and socio-economic strata. Food policy must account for these differences in order to optimize resources directed at social programs. The English version of this paper is available too at: http:// ww w.insp.mx/salud/index.html
\end{abstract}

Key words: micronutrient deficiencies; diet; malnutrition; dietary reference intakes; nutrient adequacy; national nutrition survey; Mexico

\author{
Barquera S, Rivera JA, Safdie, Flores M, \\ Campos-Nonato I, Campirano F. \\ Consumo de energía y nutrimentos \\ en niños mexicanos prescolares y escolares: \\ Encuesta Nacional de Nutrición 1999. \\ Salud Publica Mex 2003;45 supl 4:S540-S550. \\ El texto completo en inglés de este artículo también \\ está disponible en: http://www.insp.mx/salud/index.html
}

\section{Resumen}

Objetivo. Estimar el consumo de energía y nutrimentos y su adecuación en niños prescolares y escolares mexicanos, usando datos de la Encuesta Nacional de Nutrición 1999 (EN N -1999). Material y métodos. Se analizaron datos de recordatorio de dieta de 24 horas de 1309 niños prescolares y 2611 escolares en una sub-muestra representativa de la EN N-1999. Se calcularon la ingesta y la adecuación de energía y nutrimentos, y se hicieron comparaciones por región, área urbana y rural, estado socioeconómico e indigenismo. Resultados La mediana de ingestión de energía fue de $949 \mathrm{kcal}$ en prescolares y de $1377 \mathrm{kcal}$ en escolares, con adecuaciones $<70 \%$ para ambos grupos de edad. La adecuación de proteína fue $>150 \%$. Las regiones norte y Ciudad de México tuvieron la mayor ingesta de grasa y la menor ingesta de fibra. Los niños de la región sur, los de familias indígenas y los del estrato socioeconómico más pobre tuvieron la mayor ingesta de carbohidratos y fibra y la menor ingesta de grasa. Estos mismos niños tuvieron los mayores riesgos de deficiencias de vitaminas $A, C$ y folato, así como de hierro, cinc y calcio. Conclusiones México está experimentando una transición nutricional con polarización interna entre regiones y estratos socioeconómicos. Las políticas alimentarias deben to mar estas diferencias en consideración para optimizar los recursos dirigidos a programas so ciales. El texto completo en inglés de este artículo también está disponible en: http://www.insp.mx/salud/ index.html

Palabras clave: deficiencias de micronutrientes; dieta; mala nutrición; ingestas dietéticas recomendadas; adecuación nutricional; encuesta nacional de nutrición; México

(1) Centro de Investigación en N utrición y Salud, Instituto N acional de Salud Pública. Cuernavaca, Morelos, México.

Received on: A ugust 20,2002 - Acepted on: 0 ctober 2,2003

Address reprint requests to: D r. Mario Flores. Centro de Investigación en N utrición y Salud, Instituto N acional de Salud Pública. Avenida Universidad 655, colonia Santa María A huacatitlán, 62508 Cuernavaca, Morelos, México. E-mail: mflores@correo.insp.mx 
M exico is experiencing an epidemiological transition with important reductions in the prevalence of infections and undernourishment, as chronic diseases and overnourishment, increase dramatically. ${ }^{1,2}$ This profile, similar to the one observed in other countries of Latin America, has been called "delayed polarized model of transition", in which there is a lack of resolution of the transition process characterized by: a) a mixed morbi-mortality (i.e. malnutrition and infections still present, together with an increasing prevalence of obesity and chronic diseases), and b) polarization of the patterns of disease among geographical regions and socio-economic strata. ${ }^{3}$

This transition has been linked to changes in diet, physical activity and other environmental factors. ${ }^{3-5}$ Estimate of child energy and nutrient intakes in national surveys are useful to analyze these trends and to identify public health problems and possible interventions. ${ }^{6,7}$

Using information obtained from two National Nutrition Surveys (NNS) carried out in $1988^{8}$ and in $1999,9,10$ it was possible to document a decrease in the prevalence of acute malnutrition in the last decade. However micronutrient deficiencies are still a major public health problem with direct consequences in child health status. ${ }^{11}$ Micronutrient deficiencies during infancy have been strongly associated with growth retardation, diminished psychomotor development, decreased learning capacity ${ }^{12,13}$ and with increased risk of morbidity and mortality. ${ }^{14-16}$ In addition, early underourishment has been associated with the development of chronic diseases in adult hood. ${ }^{17,18}$

A previous analysis of the reported dietary intake from the NNS-1988 ${ }^{19,20}$ as well as work by other researchers $^{21}$ has identified low intakes of iron, zinc, vitamin A, folic acid, vitamin $\mathrm{C}$, and calcium in the Mexican diet. The prevalence of anemia in school children from the NNS-1999 was $19.5 \%$. It was also shown that at least 1 in five children from 5 to 11 years of age his overweight or obese. Thus, evidence of the delayed polarized model of transition is present and the analysis of child energy and nutrient intakes could be useful to understand this epidemiological profile and its determinants.

The objective of this paper is to analyze the estimated energy and nutrient intakes and adequacies in preschool age and school Mexican children, using data from the NNS-1999.

\section{Material and methods}

\section{The National Nutrition Survey 1999}

We analyzed data from the National Nutrition Survey 1999 (NNS-1999), a nation-wide, representative,

probabilistic survey with sampling power great enough to disaggregate by region and urban-rural areas. A detailed description of the survey sampling procedures and methods has been published elsewhere. ${ }^{22}$ This survey was designed to be comparable with the NNS-1988, carried out 11 years before. ${ }^{8}$ The NNS-1999 was carried out between October 1998 and March 1999.

For the analysis of polarization in the NNS 1999, the following four regions were compared: North (Baja California, Baja California Sur, Coahuila, Chihuahua, Durango, Nuevo León, Sonora, Tamaulipas); Center (Aguascalientes, Colima, Estado de México, Guanajuato, Jalisco, Michoacán, Morelos, Nayarit, Querétaro, San Luis Potosí, Sinaloa, Zacatecas); Mexico City, and South (Campeche, Chiapas, Guerrero, Hidalgo, Oaxaca, Puebla, Quintana Roo, Tabasco, Tlaxcala, Veracruz, Yucatán). Locations with more than 2499 inhabitants were classified as urban, and locations with less than 2500 inhabitants as rural.

The NNS-1999 obtained socio-economic information such as household conditions, basic services infrastructure (i.e. water source and disposal) and possession of domestic appliances (i.e. radio, television and refrigerator). A principal components factor analysis was carried out using this information to extract a main factor which explained $56 \%$ of the socioeconomic information variability. ${ }^{23,24}$ This factor was divided into tertiles and used as a relative measure of Socio-Economic Status (SES). Children from households where a native language was spoken by at least one woman 14-49 years of age were considered to have an indigenous background.

A total of 8011 preschool children (1 to 4 years of age) and 11415 school children (5 to 11 years of age) from the selected households participated in the survey.

\section{Dietary information}

A previously validated 24-hour Dietary Recall (24HDR) was administered to the mothers to obtain dietary information of a randomly selected sub-sample of 1309 preschool children and 2611 school children. Some cases were excluded from the analysis due to missing information on age and/or diet. After data cleaning, the sample analyzed for this study included a total of 1072 preschool children and 2449 school children. Standardized personnel applied the questionnaires and converted each reported consumption into grams or milliliters of food items. Aberrant food consumptions were reviewed by hand and updated when a clear mistake was detected or eliminated if the value was not biologically plausible. Energy and nutrient intakes were then estimated for foods using a comprehensive 
nutrient composition database compiled from diverse sources. ${ }^{25-30}$

\section{Data analysis}

Energy and nutrient intakes were calculated for all children and stratified according to the following factors: age, sex, region (North, Center, Mexico City and South), area (urban or rural), SES tertile and indigenous background. Energy, carbohydrate, protein and fat intakes exceeding five standard deviations from their respective means were excluded from the analysis (less than $1 \%$ of the sample). Due the skewed distributions of nutrient intakes, data are presented as medians with interquartile ranges. Nutrient adequacies were calculated using as a reference the Estimated Average Requirements (EARs) from the Dietary Reference Intakes (DRIs). ${ }^{31}$ Total energy, carbohydrate and fat adequacies were estimated relative to the Recommended Dietary Allowances (RDAs). ${ }^{32}$ Iron, zinc, vitamin $A$, vitamin $C$, and folate adequacies were calculated using the Estimated Average Requirements (EARs). ${ }^{31,33,34}$ For calcium, the Adequate Intake values (AIs) were used. ${ }^{35}$ Protein adequacy was estimated using as a reference the RDA value minus $25 \%$, to approximate the estimated average requirement. ${ }^{32}$ To test for statistical differences in nutrient intakes and adequacies across the factors, we used an ANOVA of the log-transformed intake and adequacy of each nutrient of interest. ${ }^{23,36}$ To evaluate the risk of inadequate intake, the proportion of children in this study who did not reach their correspondent EAR was calculated. In a normal population it is expected that $50 \%$ of the cases will be below the requirement, thus the percentage above this number reflects the excess prevalence at risk. ${ }^{31}$ All calculations were weighted by expansion factors to adjust for sampling effects. Statistical analysis was carried-out using SPSS version $10 .{ }^{*}$

\section{Results}

Data are presented for 1072 pre-school children (ages 1 to 4 years) and 2449 school children (ages 5 to 11 years). Socio-demographic and anthropometric characteristics of children are shown on Table I. The proportion of pre-school and school age males was 53.3\% and $50.8 \%$, respectively. Less than $33 \%$ were living in rural areas and the proportion of children with

\footnotetext{
* SPSS for Windows. Release 10.0.0. Chicago (IL): SPSS Inc, 1999.
}

\section{Table I}

Characteristics Of PRESCHOOL AND SCHOOL CHILDREN. National Nutrition Survey, Mexico, 1999

\begin{tabular}{|c|c|c|c|c|}
\hline & & $\begin{array}{c}\text { Pre-school* } \\
\%\end{array}$ & $\begin{array}{c}\text { School } \\
\%\end{array}$ & Total \\
\hline Age & 1 to 3 & $70.7^{\S}$ & & 21.0 \\
\hline \multirow[t]{4}{*}{ (years) } & 4 & 29.3 & & 9.1 \\
\hline & 5 to 6 & & 28.0 & 19.4 \\
\hline & 7 to 8 & & 29.8 & 20.8 \\
\hline & 9 to 11 & & 42.2 & 29.5 \\
\hline \multirow[t]{2}{*}{ Sex } & Male & 53.3 & 50.8 & 51.8 \\
\hline & Female & 46.7 & 49.2 & 48.2 \\
\hline \multirow[t]{4}{*}{ Regions } & North & 18.8 & 18.1 & 18.4 \\
\hline & Center & 35.8 & 34.4 & 35.0 \\
\hline & Mexico City & 12.7 & 13.9 & 13.4 \\
\hline & South & 32.7 & 33.6 & 33.2 \\
\hline \multirow[t]{2}{*}{ Area } & Rural & 30.4 & 32.1 & 31.4 \\
\hline & Urban & 69.6 & 67.9 & 68.6 \\
\hline
\end{tabular}

\begin{tabular}{llcrr} 
Indigenous & Yes & $10.2^{\#}$ & $9.3^{\S}$ & 9.4 \\
\hline background & No & 89.8 & 90.7 & 90.6
\end{tabular}

\begin{tabular}{lllll}
\multicolumn{2}{l}{ Socioeconomic Low } & 39.8 & 36.3 & 37.7 \\
\hline index (tertile) & Medium & 31.1 & 35.7 & 33.8 \\
\hline & High & 29.1 & 28.0 & 28.5
\end{tabular}

\begin{tabular}{llrrr} 
N utritional & Stunting $(<-2$ HAZ) & 17.1 & 15.9 & 16.4 \\
\hline status & Low weight $(<-2$ W AZ) & 7.5 & 4.4 & 5.7 \\
\hline & W asting $(<-2$ W HZ) & 2.0 & 1.0 & 1.4 \\
\hline & O besity $(>+2$ W HZ) & 5.5 & 9.1 & 7.6
\end{tabular}

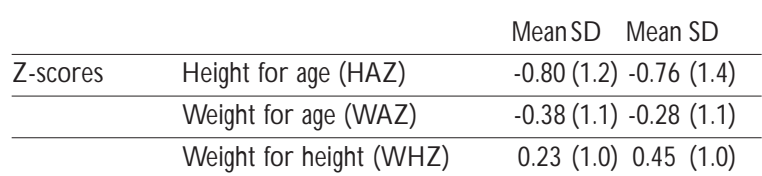

* $n=1$ 072, weighted cases: 10582157

$\neq n=2$ 449, weighted cases: 15441057

\& $n=1068$, weighted cases: 10476375

$3 n=995$, weighted cases: 9820536

\& $n=2287$, weighted cases: 14184312

indigenous background was under $11 \%$. The mean height for age Z score (HAZ) was -0.8 (SD: 1.2) for preschool children and -0.76 (SD: 1.4) in school children. Prevalences of stunting were $17 \%$ and $16 \%$ for preschool and school children, respectively. Prevalences 
of obesity were $5.5 \%$ and $9 \%$ for preschool and school children, respectively.

Children with dietary information did not differ from children without dietary information regarding sex, region, area, indigenous background, SES index and anthropometric $\mathrm{Z}$ scores. However, children with dietary data were on average three months older than children without it.

\section{Energy and macronutrients}

Nutritional intakes and percent adequacy of energy and nutrients are shown in Table II for pre-school children and in Table III for school children, by region and area of residency. The estimated median energy intake in pre-school children was $949 \mathrm{kcal}$ (percent adequacy $(\mathrm{PA})=67.4)$. Protein intake was $32.4 \mathrm{~g}(\mathrm{PA}=180.5)$ and carbohydrate intake was $120.4 \mathrm{~g}(\mathrm{PA}=63.6)$. The median fat intake was $34.5 \mathrm{~g}(\mathrm{PA}=74.9)$, and the fiber intake was $8.2 \mathrm{~g}$. The highest energy and protein adequacies were reported in Mexico City and the highest fat intake was reported in the North region. Carbohydrate intake was higher in the Center and South regions. The lowest energy, protein and fat intakes were observed in the South region. Energy, protein, carbohydrate, and fat intakes were higher in the urban compared to rural areas. Only fiber intake in grams was higher in rural areas.

In school children, the median energy intake was $1377 \mathrm{kcal}(\mathrm{PA}=69.4)$. The median protein intake was $44.7 \mathrm{~g}(\mathrm{PA}=155.5)$. Carbohydrate intake was 187.2 $\mathrm{g}(\mathrm{PA}=68.6)$, and this was the only macronutrient in which the estimated adequacy was higher in school children compared to pre-school children. The median fat intake was $47.9 \mathrm{~g}(\mathrm{PA}=72.8)$, and the fiber intake was $13.8 \mathrm{~g}$. By region, the highest energy and fat adequacies were reported in the North, while protein adequacy was higher in Mexico City. The highest carbohydrate intake, and the lowest protein and fat intakes were observed in the South.

\section{Micronutrients}

Micronutrient intake and adequacy are shown in Table II for pre-school and Table III for school children. In pre-school children, the estimated national median intakes were: $265.1 \mathrm{mcgRE}$ for vitamin A (PA=61.9), $22.3 \mathrm{mg}$ for vitamin $\mathrm{C}(\mathrm{PA}=135.0), 131.8 \mathrm{mcg}$ for folate $(\mathrm{PA}=81.1)$ and $571.5 \mathrm{mg}(\mathrm{PA}=94.2)$ for calcium. Median iron intake was $4.5 \mathrm{mg}(\mathrm{PA}=45.2)$ and zinc intake was $3.8 \mathrm{mg}(\mathrm{PA}=129.2)$. The highest vitamin $\mathrm{A}$ and calcium intakes were reported in Mexico City. Vitamin C, folate, iron and zinc intakes were higher in the North compared to other regions. The lowest vitamin A, vitamin $C$, zinc and calcium intakes were observed in the South and in rural areas. Intakes for energy and all nutrients studied were higher in urban compared to rural areas. Total fiber intake was higher in rural areas.

In school children, the estimated national median intakes were: $303.5 \mathrm{mcgRE}$ for vitamin A (PA=46.7), 29 $\mathrm{mg}$ for vitamin $\mathrm{C}(\mathrm{PA}=95), 200.2 \mathrm{mcg}$ for folate $(\mathrm{PA}=83.9), 7.1 \mathrm{mg}$ for iron $(\mathrm{PA}=69.4), 5.4 \mathrm{mg}$ for zinc $(\mathrm{PA}=52.2)$ and $677.8 \mathrm{mg}$ for calcium $(\mathrm{PA}=67.7)$. By region, the highest adequacies of vitamin $\mathrm{A}$ and $\mathrm{C}$, calci$\mathrm{um}$ and zinc and the lowest adequacies of iron were reported in Mexico City. The lowest folate intake was observed in Mexico City. The highest iron and folate intakes were observed in the North region. The lowest vitamin $A$ and vitamin $C$ intakes were reported in the South. Energy and nutrient adequacies were higher in urban compared to rural areas. Total fiber intake was higher in rural compared to urban areas.

\section{Evaluation of risk for inadequate energy and nutrient intake}

The prevalence of cases below the requirement for energy and each particular nutrient in pre-school and school children are presented in Table IV by age, sex, region, area, indigenous background, and socio-economic status. For energy and most nutrients, the proportion of cases at risk of inadequacy in pre-school children was substantially higher in rural areas (except for iron which was almost equal), and in children from indigenous backgrounds and low socio-economic status. By region, the highest proportion of inadequacy was observed in the South with the exception of folate and iron, which had a higher risk of inadequacy in Mexico City.

School children had a higher proportion of risk of inadequacy compared to pre-school children for energy and all nutrients but folate and iron. Similar to preschool children, a higher proportion of cases at risk of inadequacy was observed in school age children with an indigenous background, the lowest socio-economic status, and in the South Region. The exceptions were folate (higher in Mexico City) and iron (higher in the Center). In addition, a higher proportion of female pre-school and school children at risk for inadequacy of iron and zinc was observed, in comparison to male children.

\section{Macronutrient composition}

The macronutrient composition of diet, in terms of percent contribution to total energy intake, is shown 


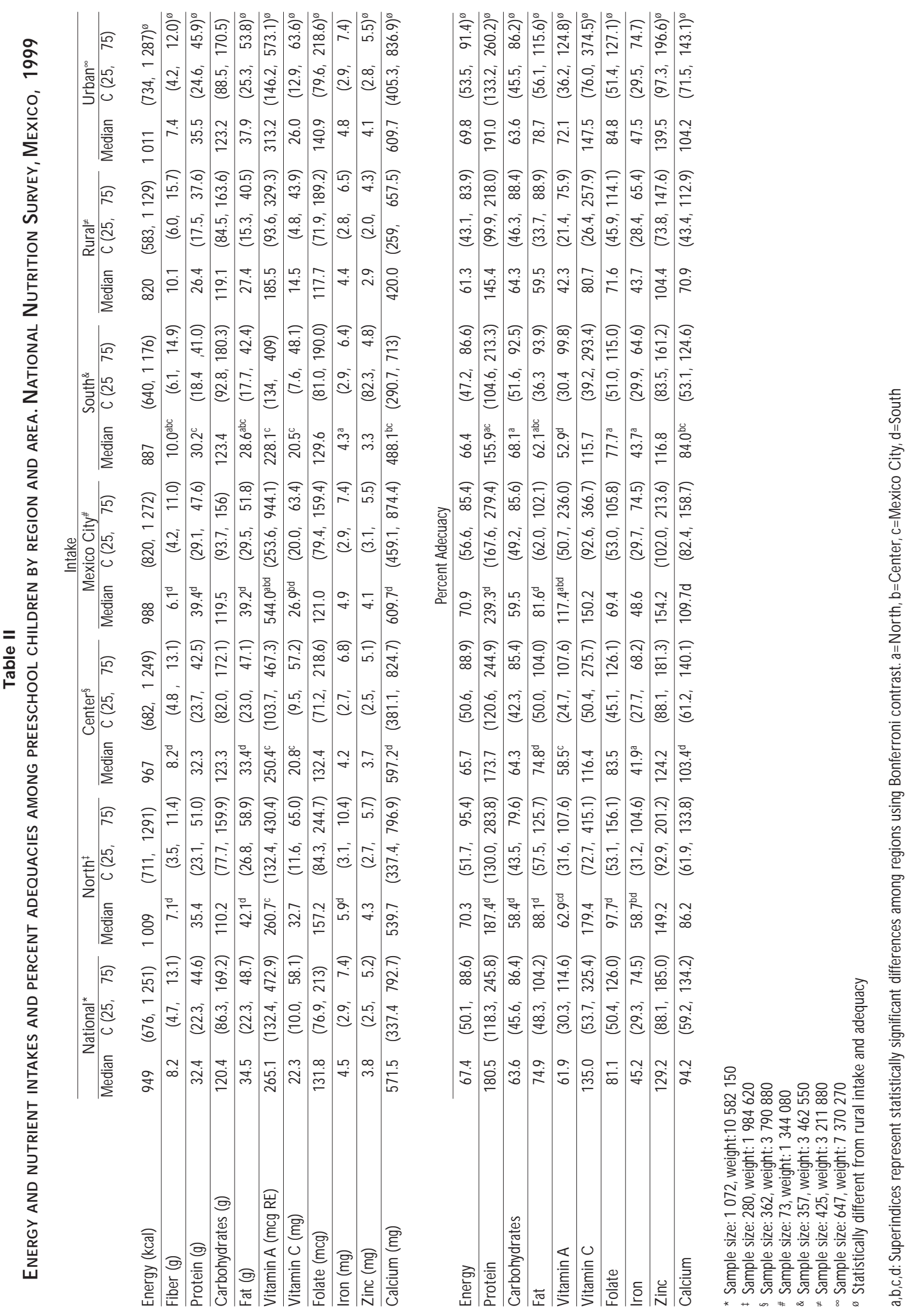




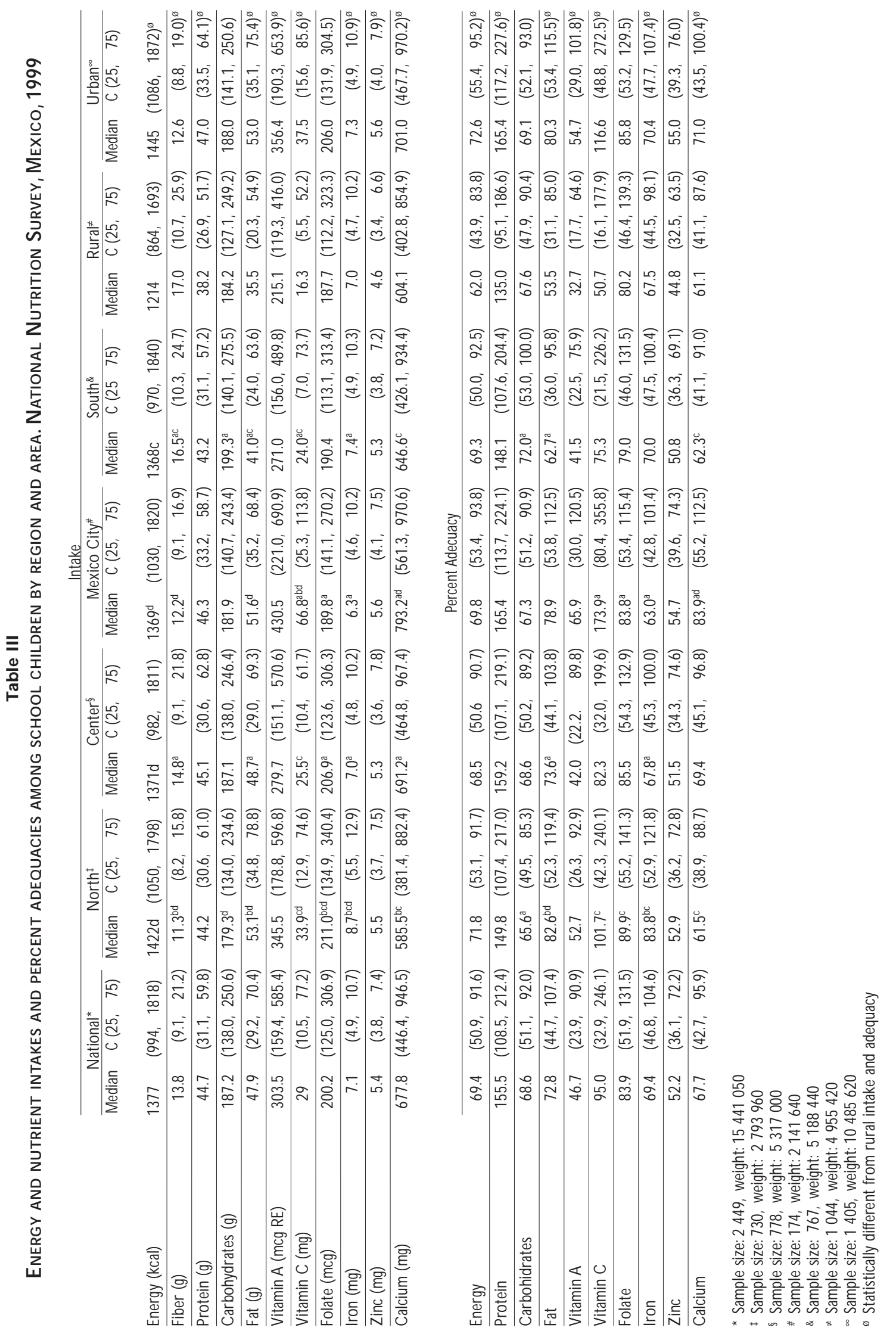


Table IV

Percent at Risk for dietary inadequacy AMONG PRE-SCHOOL AND SCHOOL CHILDREN. National Nutrition Survey, Mexico, 1999

Energy Vitamin A Vitamin C Folate Iron Zinc Calcium

\begin{tabular}{|c|c|c|c|c|c|c|}
\hline \multicolumn{7}{|l|}{$\begin{array}{c}\text { Pre-school children* } \\
\text { Age (years) }\end{array}$} \\
\hline 1 to 3 & 84.5 & 47.7 & 35.3 & 49.4 & 32.422 .0 & 50.7 \\
\hline 4 & 91.6 & 52.0 & 46.7 & 47.7 & 27.745 .8 & 73.2 \\
\hline \multicolumn{7}{|l|}{ Sex } \\
\hline Male & 85.3 & 42.3 & 36.8 & 49.8 & 28.725 .9 & 48.9 \\
\hline Female & 88.2 & 44.3 & 35.2 & 48.0 & 31.630 .2 & 57.7 \\
\hline \multicolumn{7}{|l|}{ Region } \\
\hline North & 83.2 & 40.7 & 31.8 & 42.4 & 26.524 .7 & 55.1 \\
\hline Center & 88.1 & 46.5 & 37.3 & 46.4 & 32.927 .3 & 47.8 \\
\hline Mexico City & 76.7 & 25.6 & 19.8 & 57.4 & 30.417 .3 & 39.4 \\
\hline South & 89.8 & 48.1 & 43.6 & 52.5 & 28.734 .4 & 62.6 \\
\hline \multicolumn{7}{|l|}{ Area } \\
\hline Rural & 91.7 & 57.6 & 50.3 & 56.7 & 29.839 .2 & 68.6 \\
\hline Urban & 83.3 & 37.2 & 30.0 & 45.8 & 30.123 .0 & 46.2 \\
\hline Indigenous Yes & 97.2 & 63.5 & $62.3^{\S}$ & 56.5 & 26.643 .8 & 71.4 \\
\hline background ${ }^{\ddagger}$ No & 86.0 & 41.1 & 33.4 & 48.3 & 30.426 .2 & 51.0 \\
\hline \multicolumn{7}{|c|}{ Socioeconomic index (tertile) } \\
\hline High & 79.6 & 33.4 & 26.5 & 47.5 & 28.218 .0 & 42.8 \\
\hline Medium & 87.9 & 50.3 & 36.3 & 49.2 & 32.828 .2 & 57.3 \\
\hline Low & 92.8 & 64.4 & 54.6 & 50.0 & 32.042 .2 & 73.7 \\
\hline Total & 86.6 & 43.2 & 36.1 & 49.0 & 30.027 .8 & 52.9 \\
\hline \multicolumn{7}{|l|}{ School children§ } \\
\hline \multicolumn{7}{|l|}{ Age (years) } \\
\hline 5 to 6 & 84.3 & 44.2 & 39.7 & 42.7 & 22.835 .4 & 69.6 \\
\hline 7 to 8 & 82.1 & 45.4 & 40.3 & 36.1 & 17.228 .1 & 62.7 \\
\hline 9 to 11 & 82.6 & 64.2 & 56.4 & 59.1 & 27.165 .9 & 92.7 \\
\hline \multicolumn{7}{|l|}{ Sex } \\
\hline Male & 81.3 & 50.5 & 47.4 & 45.3 & 18.742 .9 & 76.2 \\
\hline Female & 84.7 & 55.8 & 46.5 & 50.1 & 27.549 .6 & 78.5 \\
\hline \multicolumn{7}{|l|}{ Region } \\
\hline North & 84.4 & 47.9 & 42.7 & 44.8 & 17.744 .2 & 81.5 \\
\hline Center & 83.2 & 55.6 & 52.4 & 46.1 & 26.845 .6 & 75.5 \\
\hline Mexico City & 81.0 & 38.3 & 26.1 & 47.0 & 25.339 .2 & 64.2 \\
\hline South & 81.7 & 59.2 & 52.4 & 51.0 & 20.850 .5 & 82.2 \\
\hline \multicolumn{7}{|l|}{ Area } \\
\hline Rural & 79.4 & 67.2 & 62.2 & 50.3 & 24.054 .8 & 82.6 \\
\hline Urban & 87.6 & 46.3 & 39.9 & 46.4 & 22.442 .0 & 74.8 \\
\hline Indigenous Yes & 89.3 & $66.6^{\#}$ & $68^{\alpha}$ & 49.7 & 21.352 .8 & 80.9 \\
\hline background No & 82.2 & 51.7 & 44.9 & 47.4 & 23.145 .4 & 76.9 \\
\hline \multicolumn{7}{|c|}{ Socioeconomic index (tertile) } \\
\hline High & 76.7 & 38.4 & 32.8 & 43.2 & 22.337 .1 & 73.3 \\
\hline Medium & 84.7 & 54.4 & 45.6 & 49.9 & 22.046 .8 & 75.3 \\
\hline Low & 87.7 & 70.2 & 67.5 & 50.4 & 24.956 .9 & 85.1 \\
\hline Total & 82.9 & 53.0 & 46.9 & 47.6 & 22.946 .1 & 77.3 \\
\hline \multicolumn{7}{|c|}{ 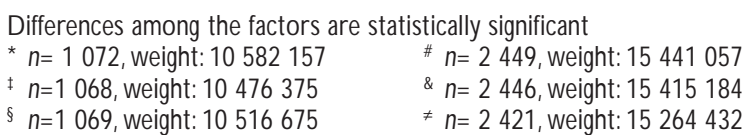 } \\
\hline
\end{tabular}

on Table V. In preschool children, carbohydrates accounted for $53 \%$ of energy intake, protein contributed with $13.8 \%$, and fat provided $34.1 \%$. The proportion of energy from carbohydrate was higher in the South compared to other regions, and highest in rural areas compared to urban. Proportion of energy from protein and fat was lower in the South and in rural areas. Indigenous children had the higher proportion of energy from carbohydrate and the lowest proportion of energy from other macronutrients. The same trends were observed in school children. In school children, carbohydrates accounted for $56.1 \%$ of total energy intake, while protein provided $12.8 \%$, and fat accounted for $32.4 \%$.

\section{Discussion}

This is the first time in 10 years that dietary information is obtained from pre-school children, and the first time ever that this information is collected from school age children in Mexico by a nationally representative survey.

Children in the South region, indigenous children, and those in the lowest socio-economic stratum, had higher fiber and carbohydrate intake with lower fat intake. These children also showed the higher risks of inadequacies for vitamins $\mathrm{A}, \mathrm{C}$ and folate, and for iron, zinc and calcium. Deficiencies were more marked in rural areas, compared to urban. Energy and carbohydrate adequacies were below $70 \%$ for both preschool and school children.

The 24-hour dietary recall is the most widely used method to assess dietary intake and has been extensively used in national and population-based surveys. ${ }^{37}$ However, it should be noted that the 24-hour dietary recall tends to under-report energy and nutrient intake. ${ }^{37,38}$ One could confirm -and roughly quantify the magnitude of this under-report by looking at the median percent adequacy of energy in children in the higher socioeconomic group, which was $75 \%$ for preschool and $80 \%$ for school children. Since in this socio-economic stratum one could expect that the percent adequacy of energy would be at least $100 \%$, the magnitude of energy and nutrient under-reporting would be at least around 20 to $25 \%$. As a consequence, the proportion of children at risk of nutrient inadequacies could be overestimated in the present study. Moreover, we do not know if this dietary under-reporting differs by SES status, maternal schooling or literacy, or the child's nutritional status in the present study. Thus, caution is advised, and more studies are needed to clarify this issue.

Clearly, the energy and macronutrient consumption follows a geographical pattern associated with 


\section{Table V \\ Proportion of energy from macronutrients (\%) For PRE-SCHOOL AND SCHOOL CHILdRen. National Nutrition Survey, Mexico, 1999}

\begin{tabular}{|c|c|c|c|c|c|c|c|c|}
\hline \multirow{2}{*}{ Pre-school children* } & \multicolumn{2}{|c|}{ Carbohydrates } & \multicolumn{2}{|c|}{ Protein } & \multicolumn{2}{|r|}{ Fat } & \multicolumn{2}{|c|}{ Saturated fat } \\
\hline & & & & & & & & \\
\hline Age (years) $)^{\ddagger}$ & Median & $C(25,75)$ & Median & $C(25,75)$ & Median & $C(25,75)$ & Median & $C(25,75)$ \\
\hline 1 to 3 & 52.1 & $(43.4,62.4)$ & 13.9 & $(11.5,16.7)^{5}$ & 34.8 & $(26.4,42.1)$ & 13.7 & $(8.1,18.7)$ \\
\hline 4 & 55.4 & $(45.8,65.0)$ & 13.4 & $(11.3,15.5)$ & 32.7 & $(23.8,40.3)$ & 12.9 & $(6.5,16.5)$ \\
\hline \multicolumn{9}{|l|}{$\operatorname{Sex}{ }^{\S}$} \\
\hline Male & 53.3 & $(44.9,63.5)$ & 13.9 & $(11.4,16.3)$ & 34.4 & $(25.0,40.0)$ & 13.5 & $(7.7,18.6)$ \\
\hline Female & 52.6 & $(43.6,63.8)$ & 13.6 & $(11.4,16.5)$ & 33.2 & $(25.9,42.0)$ & 13.0 & $(7.5,17.7)$ \\
\hline \multicolumn{9}{|l|}{ Region } \\
\hline North & 48.9 & $(39.5,56.8)$ & 14.2 & $(12.2,17.2)$ & 37.2 & $(30.4,44.4)$ & 15.4 & $(10.4,20.1)$ \\
\hline Center & 51.5 & $(43.7,61.7)$ & 13.9 & $(11.4,16.4)$ & 35.9 & $(26.4,42.3)$ & 14.5 & $(9.0,20.1)$ \\
\hline Mexico City & 51.8 & $(44.2,57.1)$ & 14.7 & $(13.2,17.0)$ & 35.1 & $(30.0,40.3)$ & 17.0 & $(13.5,18.4)$ \\
\hline South & 60.7 & $(49.7,70.3)$ & 12.8 & $(10.8,15.1)$ & 28.8 & $(20.1,37.2)$ & 8.7 & $(4.2,13.8)$ \\
\hline \multicolumn{9}{|l|}{ Area } \\
\hline Rural & 59.9 & $(49.0,69.8)$ & 12.8 & $(10.9,14.8)$ & 28.9 & $(20.1,38.1)$ & 7.9 & $(3.6,13.6)$ \\
\hline Urban & 51.0 & $(42.9,60.5)$ & 14.2 & $(11.9,16.7)$ & 36.0 & $(27.8,42.3)$ & 15.2 & $(10.0,19.8)$ \\
\hline Indigenous Yes & 61.2 & $(53.7,73.4)$ & 11.8 & $(9.9,14.3)$ & 26.5 & $(14.0,32.7)$ & 5.4 & $(1.7,11.5)$ \\
\hline background $d^{\ddagger} \mathrm{No}$ & 52.3 & $(43.7,62.6)$ & 13.9 & $(11.6,16.5)$ & 35.2 & $(26.2,41.7)$ & 14.0 & $(8.6,18.7)$ \\
\hline \multicolumn{9}{|c|}{ Socioeconomic index (tertile) } \\
\hline High & 47.7 & $(43.4,57.1)$ & 14.5 & $(12.7,17.2)$ & 37.6 & $(30.6,42.1)$ & 16.0 & $(11.9,20.1)$ \\
\hline Medium & 52.9 & $(42.2,61.2)$ & 13.8 & $(11.7,16.4)$ & 35.1 & $(27.1,42.3)$ & 14.2 & $(9.2,19.2)$ \\
\hline Low & 62.8 & $(51.3,73.3)$ & 12.3 & $(10.5,14.6)$ & 25.9 & $(17.5,35.8)$ & 6.1 & $(2.9,11.8)$ \\
\hline Total & 53.0 & $(44.0,63.5)$ & 13.8 & $(11.4,16.4)$ & 34.1 & $(25.5,41.3)$ & 13.5 & $(7.7,18.3)$ \\
\hline
\end{tabular}

School children\#

\begin{tabular}{|c|c|c|c|c|c|c|c|}
\hline \multicolumn{8}{|l|}{ Age (years) } \\
\hline 5 to 6 & 54.9 & $(47.8,63.4)$ & 12.8 & $(10.7,14.6)$ & 33.1 & $(25.8,40.1)$ & - \\
\hline 7 to 8 & 55.6 & $(47.6,65.5)$ & 12.8 & $(11.0,15.3)$ & 32.8 & $(24.5,39.7)$ & \\
\hline 9 to 11 & 57.4 & $(48.8,67.2)$ & 12.8 & $(11.1,15.1)$ & 31.3 & $(22.5,38.1)$ & - \\
\hline \multicolumn{8}{|l|}{$\operatorname{Sex} \S$} \\
\hline Male & 56.3 & $(48.2,65.8)$ & 12.8 & $(11.1,14.9)$ & 32.1 & $(23.5,38.8)$ & - \\
\hline Female & 55.8 & $(48.1,64.7)$ & 12.7 & $(10.7,15.1)$ & 32.7 & $(24.6,39.1)$ & - \\
\hline \multicolumn{8}{|l|}{ Region } \\
\hline North & 52.2 & $(45.4,59.8)$ & 12.6 & $(10.7,14.7)$ & 35.4 & $(29.0,42.2)$ & - \\
\hline Center & 55.7 & $(47.9,65.4)$ & 13.1 & $(10.9,15.2)$ & 32.9 & $(23.9,39.2)$ & - \\
\hline Mexico City & 55.3 & $(48.7,62.2)$ & 12.9 & $(11.5,15.8)$ & 33.1 & $(26.7,39.7)$ & - \\
\hline South & 59.8 & $(50.3,69.9)$ & 12.7 & $(10.9,14.6)$ & 29.3 & $(19.6,36.7)$ & - \\
\hline \multicolumn{8}{|l|}{ Area } \\
\hline Urban & 54.1 & $(47.1,62.2)$ & 12.9 & $(11.1,15.2)$ & 33.8 & $(27.1,40.1)$ & - \\
\hline Rural & 62.3 & $(51.4,71.8)$ & 12.4 & $(10.7,14.5)$ & 27.1 & $(18.5,36.3)$ & - \\
\hline Indigenous Yes & 67.3 & $(54.4,77.4)$ & 12.3 & $(10.6,13.8)$ & 22.9 & $(14.9,31.8)$ & - \\
\hline background $\mathrm{N}_{0}$ & 55.5 & $(47.9,64.1)$ & 12.8 & $(11.1,15.1)$ & 33.1 & $(25.1,39.5)$ & - \\
\hline \multicolumn{8}{|c|}{ Socioeconomic index (tertile) } \\
\hline High & 51.8 & $(45.4,59.8)$ & 13.1 & $(10.7,15.5)$ & 35.9 & $(30.6,41.8)$ & - \\
\hline Medium & 55.6 & $(48.4,64.1)$ & 12.9 & $(11.2,15.1)$ & 32.2 & $(25.1,38.4)$ & - \\
\hline Low & 51.8 & $(45.4,59.8)$ & 13.1 & $(10.7,15.5)$ & 35.9 & $(30.6,41.8)$ & - \\
\hline Total & 56.1 & $(48.1,65.5)$ & 12.8 & $(10.9,14.9)$ & 32.4 & $(24.1,39.1)$ & - \\
\hline
\end{tabular}

* $n=1072$, weight: 10582157

₹n=1068, weight: 10476375

$\S$ D ifferences were statistically significant between catego ries except where marked by this symbol \# $n=2449$, weight: 15441057 
morbidity and mortality, explaining some characteristics of the epidemiologic and nutrition transition. The North region, which has the highest prevalence of obesity at the national level, has higher energy and fat percent adequacies. Likewise, urban areas, higher socio-economic status and children without indigenous background showed higher levels of energy and fat consumption with a lower consumption of fiber and carbohydrates. These patterns were observed previously by our group analyzing the Mexican National Household Income and Expenditure Surveys from 1984 to $1998 .{ }^{1}$ This suggests that Mexico is still in a different stage of the epidemiological and nutrition transition, as compared to more developed countries in which the more educated groups adopt healthier lifestyles. ${ }^{39,40}$

On the other hand, micronutrient information suggests important risks for deficiencies in preschool and school children. Children with higher risks of inadequacies were those living in rural areas, in the South region of the country and those with an indigenous background. These results agree with previous reviews on micronutrient deficiencies in Mexico and Latin America, related to the importance of inadequacy risks for calcium, vitamin $\mathrm{A}$, vitamin $\mathrm{C}$, zinc and iron in disadvantaged populations. ${ }^{21,41}$

The EAR is the median usual intake value that is estimated to meet the requirement of half the healthy individuals in a life stage and gender group. ${ }^{31}$ At this level of intake, the other half of the individuals would not have met their needs. However, due to the methodological procedures involved in the estimation of intake it is necessary to consider with caution this information due to the following considerations:

In the case of calcium, an EAR has not been established. Therefore we used the AI as a reference. The AI reflects the mean intake of a healthy population within a specific gender and age group; thus, the proportion of children under the AI does not necessarily reflect inadequate intakes.

The 24-hour dietary recall questionnaire did not considered the vitamin A mega-dose supplementation program, a nation-wide strategy carried out by the Ministry of Health in order to prevent vitamin A deficiency in children. Thus, reported vitamin A intakes could be underestimated. This would lead to an overestimation of the risk of vitamin A inadequacy. The risk of inadequacy for iron did not consider dietary sources of the element, neither its biochemical form (heme vs. non-heme). This is important, since the Mexican diet contains high quantities of fiber, phytates, phosphates and tannins which are among the most powerful depressants of iron bio-availability. Therefore, the risk of iron deficiency could be higher than that reported in this study if the non-heme form of iron is an important source of the mineral. Our results are consistent with other studies that have identified zinc deficiency as a major nutritional problem in Mexican children. ${ }^{11}$ Moreover, similar to iron, zinc faces bio-availability problems related to the presence of dietary inhibitors such as fiber, phytates and so on. Thus, interventions aimed at improving zinc intake in children should be encouraged. Vitamin $C$ risk of inadequacy was higher than could be expected considering that Mexico produces large quantities of citrus and tropical fruits, which are excellent sources of the vitamin. Thus, consumption of these foods by children should be encouraged to improve their vitamin $C$ intake. Folate intakes were lower in the urban areas and in the North and Mexico City regions, compared to the South and rural areas. This suggests different dietary patterns among strata, particularly in relation to the consumption of green leafy vegetables.

The data showed important risks of inadequacies for various micronutrients, which are essential for normal child health and development. This can pose a risk for their health and nutrition status, and actions are needed to address this problem. Micronutrient supplementation has proved to be a very effective, lowcost strategy to control nutrient deficiencies in developing countries, and thus, it should be encouraged. ${ }^{15,16}$

However, while some interventions, such as multiple micronutrient supplementation in young children are useful for resolving micronutrient deficiencies in the short term, it is worthwhile to consider long term interventions such as food fortification and diet diversification. This would have particular importance in school-age children, because dietary habits are acquired during this period of life. Moreover, diverse studies have shown that people who consume a diversity of foods (i.e. fruits, vegetables and fiber) have a reduced risk of obesity and chronic diseases. ${ }^{42-47}$ The prevalence of overweight or obesity has been reported to be between 13 and $26 \%$ for school-age children in this survey. ${ }^{10}$ Thus, together with micronutrient deficiencies, a call for major actions aimed to prevent these health problems starting at early ages is necessary. ${ }^{48-52}$ There is increasing evidence that the risk of cardiovascular diseases, which represent the first cause of mortality in the country, begins in childhood. ${ }^{53} \mathrm{~A}$ careful exploration of nutrition education in children must be carried out, aiming to improve the quality of their diet and increase physical activity to reduce the prevalence of coronary heart disease and other non-communicable chronic diseases in later life..$^{39,49,54,55}$ Finally, it is important for health planners to review the country is food and nutrition program targeting, and to evaluate 
the impact of nutrition interventions, in order to optimize resources and to guarantee the effectiveness of these actions.

Our data showed important differences in nutrient intakes and inadequacies between rural and urban areas, children from indigenous and non-indigenous backgrounds and national regions. Policy should direct resources to the most vulnerable groups in order to improve the nutritional status of children.

\section{Acknowledgments}

We would like to acknowledge the collaboration of Eric Monterrubio, BS, and Noemí Figueroa, BS, a for the database management; Ivonne Ramírez, BS, and Alejandra Gasca, MD for database cleaning and Maribel Porcayo, BS, in the compilation of the nutrient composition database.

\section{References}

1. Rivera J, Barquera S, Campirano F, C ampos I, Safdie M, Tovar V. Epidemiological and nutritional transition in Mexico: Rapid increase of non-communicable chronic diseases and obesity. Public Health $\mathrm{N}$ utr 2002;14:113-122.

2. Bobadilla J, Frenk J, Lozano R, Frejka T, Stern C. The epidemiologic transition and health priorities. In: Jamison D, Ed. D isease control priorities in developing countries. N ew York (NY): 0 xford University Press, 1993.

3. Frenk J, FrejkaT, Bobadilla JL, Stern C, Sepúlveda J, José MV.The epidemiologic transition in Latin A merica. Bol 0 ficina Sanit Panam 1991;111:485-496.

4. Popkin BM.The nutrition transition in low-income countries:An emerging crisis. N utr Rev 1994;52:285-298.

5. Drewnowski A, Popkin BM. The nutrition transition: $\mathrm{N}$ ew trends in the global diet. N utr Rev 1997;55:31-43.

6. Romieu I, Hernández-Avila M, Rivera JA, Ruel MT, Parra S. D ietary

studies in countries experiencing a health transition: Mexico and

Central A merica.Am J C lin N utr 1997;65:1159S-1165S.

7. Barquera S, Rivera J, Gasca-G arcía A. Políticas y programas de alimentación y nutrición en México. Salud Publica Mex 2001;43:1-14.

8. Sepúlveda-Amor J, Lezana MA, Tapia-C onyer R,Valdespino JL, Madrigal $H$, Kumate J. N utritional status of pre-school children and women in México: Results of a probabilistic national survey. Gac Med Mex 1990;126:207-224.

9. Rivera-D ommarco J, Shamah-Levy T,Villalpando-Hernández S, González-C ossío T, Hernández-Prado B, Sepúlveda-A mor J. C apítulo 2: Preescolares. In: Rivera-D ommarco J, Shamah-Levy T,Villalpando $S$ et al, ed. Encuesta $\mathrm{N}$ acional de N utrición 1999. Estado N utricio de Niños y Mujeres de México.Vol. ISBN 968-6502-54-8. Cuernavaca, Morelos: Instituto Nacional de Salud Pública, 2000:29-61.

10. Hernández-Prado B, Rivera-D ommarco J, Shamah-Levy T, GonzálezCossío T, Hernández-Prado B, Sepúlveda-A mor J. Escolares. En: RiveraD ommarco J, Shamah-Levy T,Villalpando S, G onzález-C ossío T, Hernández-Prado B, Sepúlveda-Amor J, ed. Encuesta $\mathrm{N}$ acional de Nutrición 1999. Estado N utricio de Niños y Mujeres de México. Cuernavaca, Morelos: Instituto N acional de Salud Pública, 2000:69-99.
11.Villalpando S, Rivera-D ommarco J, Shamah-Levy T, González-Cossío T, Hernández-Prado B, Sepúlveda-Amor J. Micronutrimentos. In: RiveraD ommarco J, Shamah-Levy T,Villalpando S, G onzález-C ossío T, Hernández-Prado B, Sepúlveda-A mor J, Ed. Encuesta N acional de Nutrición 1999. Estado Nutricio de N iños y Mujeres de México. Cuernavaca, Morelos: Instituto N acional de Salud Pública, 2000:179-238. 12.Allen LH.The nutrition CRSP:W hat is marginal malnutrition, and does it affect human function? N utr Rev 1993;51:255-267.

13. Pollitt E, Saco-Pollit C, Jahari A, H usaini M, Huang J. Effects of an energy and micronutrient supplement on mental development and behavior under natural conditions in undernourished children in Indonesia. Eur J Clin N utr 2000;54:80-90.

14. Pelletier D, Frongillo E, Habitcht J P. Epidemiologyc evidence for a potentiation effect of malnutrition on child mortality. Am J Public Health 1993;83:1130-1133.

15. Beaton G, Martorell R,Aronson K, Edmonston A, McC abe G, Ross A. Effectiveness of vitamin $A$ supplementation in the control of young child mortality in developing countries. N utrition Policy D iscussion Paper $\mathrm{N}$ o. 13 ACC/SCN 1993. N ew York. United N ations Press.

16. Black R, Sazawal S. Zinc and childhood infectious disease morbidity and mortality. Br J N utr 2001;85:S125-S129.

17. Barker DJ, 0 smond C, Simmonds SJ,W ield GA. The relation of small head circumference and thinness at birth to death from cardiovascular disease in adult life. BMJ 1993;306:422-426.

18. Barker DJ, Clark PM. Fetal undernutrition and disease in later life. Rev Reprod 1997;2:105-112.

19. Hernández B, Peterson K, So bol A, Rivera J, Sepúlveda J, Lezana MA. 0 verweight in 12-49 year-old women and children under 5 years of age in México. Salud Publica Mex 1996;38:178-188.

20. Martínez-Salgado H, Parra-C abrera S, Rivera-D ommarco J. Personal communication:A decuación de la ingestión dietética de energía y micronutrimentos en niños de 1 a 5 años de edad: resultados de una encuesta probabilística nacional. Instituto $\mathrm{N}$ acional de Salud Pública, Cuernavaca, Morelos, 1998.

21. Rosado J, Bourges H, Saint-Martín B. D eficiencia de vitaminas y minerales en México. Una revisión crítica del estado de la información: deficiencia de vitaminas. Salud Publica Mex 1995;37:452-461.

22. Resano-Pérez E,Vicencio-Acevedo C, Landeros-D íaz A, Shamah-Levy T, Rivera-D ommarco J. Metodología. In: Rivera-D ommarco J, ShamahLevy T,Villalpando-Hernández S, G onzález-C ossío T, Hernández-Prado B, Sepúlveda-Amor J, Ed. Encuesta N acional de Nutrición II: Estado $\mathrm{N}$ utricio de $\mathrm{N}$ iños y Mujeres en México. Cuernavaca, Morelos: Instituto N acional de Salud Pública, 2000:21-28.

23. Kleinbaum D, Kupper L, Muller K, N izam A. Applied regression analysis and other multivariable methods. In: Kugushev A, Ed. Pacific Grove, California: Brooks/C ole Publishing Company, 1998:798. 24. Reyment R, Jöreskog K. A pplied factor analysis in the natural sciences. C ambridge, UK: C ambridge University Press, 1996:371. 25. US D epartment of A griculture, A gricultural Research Service. USDA N utrient D atabase for Standard Reference, Release 13. N utrient D ata Laboratory, 1999.

26. Food composition database. Davis, (CA): University of California Davis, 1998.

27. Instituto de N utrición de Centroamérica y Panamá. Tabla de composición de alimentos para uso en América Latina. In: PAHO, IN CAP, Ed. Guatemala: - IC N N D, 1961:98.

28. Morales J, Babinsky V, Bourges H, Camacho M.Tablas de composición de alimentos mexicanos del Instituto $\mathrm{N}$ acional de Ciencias Médicas y Nutrición Salvador Zubirán. México, DF: Instituto N acional de Nutrición, 1999.

29. Muñoz M, Chávez A, Pérez-Gil F.Tablas de valor nutritivo de los alimentos de mayor consumo en México. Mexico, DF: Editorial Pax, 1996:330. 
30. Souci S, Fachmann W, Kraut H. Food composition and nutrition tables. In: Senser HSuF, Ed. Stuttgart: Medpharm Scientific Publications: CRC Press, 2000.

31. Institute of Medicine. D ietary reference intakes:A pplications in dietary assessment. W ashington, DC : Institute of Medicine, $\mathrm{N}$ ational Academy Press, 2000:285.

32. National Research C ouncil. Recommended dietary allowances. W ashington, DC: $N$ ational A cademy Press, 1989.

33. Institute of Medicine. Dietary reference intakes for:Vitamin $C$, vitamin $E$, selenium and carotenoids. W ashington DC: Institute of Medicine, N ational A cademy Press, 2000:506.

34. Institute of Medicine. Dietary reference intakes for:Vitamin A, vitamin $\mathrm{K}$, arsenic, boron, chromium, copper, iodine, iron, manganese, molybdenum, nickel, silicon, vanadium, and zinc.W ashington DC: Institute of Medicine, $N$ ational A cademy Press, 2001:650. 35. Institute of Medicine. D ietary reference intakes for: C alcium, phosphorus, magnesium, vitamin $D$ and fluoride. W ashington $D C$ : Institute of Medicine, $\mathrm{N}$ ational A cademy Press, W ashington, DC. 2000:432.

36. Millns H,W oodward M, Bolton-Smith C. Is it necessary to transform nutrient variables prior to statistical analyses? Am J Epidemiol 1995;141:251-262.

37.W illett W. N utritional epidemiology. In: MacMahon B, Ed. Monographs in epidemiology and biostatistics. Vol. 15. N ew York: 0 xford University Press, Inc., 1990:396.

38. Campirano F, Barquera S, Rivera J, Hernández-Prado B, Flores M, Monterrubio E. Estimation of energy under-reporting in obese and non-obese Mexican women using different equations:A nalysis of the Mexican N utrition Survey. Ann N utr Metabol 2001;45:146.

39. Muller MJ, Koertzinger I, Mast M, Langnase K, G rund A, Koertringer I. Physical activity and diet in 5 to 7 years old children. Public Health $\mathrm{N}$ utr 1999;2:443-444.

40. Popkin BM.The shift in stages of the nutrition transition in the developing world differs from past experiences. Public $\mathrm{H}$ ealth $\mathrm{N}$ utr 2002;5:93-103.

41. 0 'D onnell AM. The feeding of children in Latin A merica. Arch Latinoamer N utr 1988;38:685-704.
42. Fung TT, W illett W C, Stampfer MJ, Manson JE, Hu FB. D ietary patterns and the risk of coronary heart disease in women. Arch Intern Med 1857;161:1857-1862.

43. Hu FB, Manson JE, Stampfer MJ. D iet, lifestyle, and the risk of type 2 diabetes mellitus in women. N Engl J Med 2001;345:790-797.

44. Hu FB, W illett W C. D iet and coronary heart disease: Findings from the N urses' Health Study and Health Professionals' Follow-up Study. Journal of N utrition, Health \& Aging 2001;5:132-138.

45. Liu S, Manson JE, Lee IM, C ole SR, H ennekens CH, W illet W C et al. Fruit and vegetable intake and risk of cardiovascular disease:The W omen's Health Study.Am J Clin N utr 2000;72:922-928.

46. Liu S, Buring JE, Sesso HD, Rimm EB, W illett W C, Manson JE. A prospective study of dietary fiber intake and risk of cardiovascular disease among women. J Am Coll Cardiol 2002;39:49-56.

47. Tucker K, Selhub J,W ilson P, Rosenberg I. D ietary intake pattern relates to plasma folate and homocysteine concentrations in the Framingham Hearth Study. J N utr 1996;126:3025-3031. 48. Tucker K, Spiro A, W eiss S.Variation in food and nutrient intakes among older men:Age, and other socio-demographic factors. N utr Res 1995;15:161-176.

49. Bedinghaus J, D oughten S. C hildhood nutrition: From breastmilk to burgers. Primary Care 1994;21:655-672.

50. Borra ST, Schwartz NE, Spain CG, N atchipolsky M M. Food, physical activity, and fun: Inspiring America's kids to more healthful lifestyles. J Am Diet Assoc 1995;95:816-823.

51. Ernst N D, 0 barzanek E. Child health and nutrition: 0 besity and high blood cholesterol. Preventive Medicine 1994;23:427-436.

52. Kennedy E, Goldberg J.W hat are American children eating? Implications for public policy. N utr Rev 1995;53:111-126.

53. Berenson GS, Srinivasan SR, N icklas TA. Atherosclerosis: A nutritional disease of childhood. Am J Cardiol 1998;82.

54. W eber JL, C unningham-Sabo L, Skipper B. Portion-size estimation training in second- and third-grade American Indian children. A m J Clin N utr 1999;69.

55. Sahota P, Rudo If MC, Dixey R, Hill AJ, Barth JH, Cade J. Randomised controlled trial of primary school based intervention to reduce risk factors for obesity. BMJ 2001;323:1029-1032. 